\title{
ARCHITECTURAL FEATURES AND CONCEPTION OF OVERALL CONSTRUCTION MODE OF YI SETTLEMENTS
}

\author{
$\mathrm{Ru} \mathrm{YANG}^{1}$ and Zhentao $\mathrm{QIN}^{2 *}$
}

\author{
${ }^{1}$ The College of Civil and Architectural Engineering, Panzhihua College, Panzhihua 617000 \\ Panzhihua, China \\ ${ }^{2}$ The College of Mathematics and Computer Science, Panzhihua College, Panzhihua 617000 \\ Panzhihua, China \\ *Corresponding author: qzt2008@sina.com
}

(Received May 2, 2018; accepted July 31, 2018)

Key words: traditional dwellings, architectural style, culture, villages, modernization

\begin{abstract}
Yi is an ancient and brilliant nation, with its ancestors rooted in Panxi rift, forming a large number of unique and dazzling national cultures in the long national development path with the nutriment of the Jinsha River and the An'ning River. With the development of times, science and technology promote the integration of national culture. The remote, poor and backward traditional Yi settlements are facing constant impacts of modernization on material and spirit. The renovation of traditional Yi dwellings and the construction of small towns blindly copy the construction model of large and medium-sized cities. The destruction of the living environment is caused by economic development and natural disasters. The destruction of the traditional architectural style of Yi dwellings has changed the living environment of Yi, and the dwellings have gradually lost their long-standing architectural features and advantages. Therefore, it is urgent to improve the income and living standards of the residents in Yi region, build a livable living environment, and protect and inherit the Yi culture. The work analyzed the characteristics of Yi villages in Panzhihua, and proposed the overall construction mode of Yi settlement environment in modernization.
\end{abstract}

Palabras clave: asentamientos tradicionales, estilos arquitectónicos, cultura, villas, modernización

\section{RESUMEN}

Yi es un pueblo antiguo y brillante. Las raíces de sus ancestros se encuentran en el valle tectónico (rift) de Panxi y comprenden un gran número de culturas únicas y deslumbrantes en el largo desarollo nacional, nutridas por los ríos Jinsha y An'ning. Con el paso del tiempo la ciencia y la tecnología promueven la integración de la cultura nacional. Los remotos, pobres y atrasados asentamientos de Yi enfrentan los constantes impactos de la modernización en lo material y en lo espiritual. La renovación de los asentamientos tradicionales de Yi y la construcción de pequeños pueblos copia ciegamente el modelo de las ciudades medianas y grandes. La destrucción del ambiente de vida es causada por el desarrollo económico y por los desastres naturales. La destrucción del estilo tradicional de arquitectura de los asentamientos de Yi ha cambiado el ambiente de vida y gradualmente se han perdido las características y ventajas del antiguo estilo arquitectónico. Por 
lo anterior, es urgente mejorar el ingreso y los estándares de vida de los residentes de la región de Yi, construir un ambiente vivible y proteger la herencia de la cultura Yi. Este trabajo analiza las características de las villas de Panzhihua en Yi y propne la reconstrucción completa del ambiente de los asentamientos en la modernización.

\section{INTRODUCTION}

Yi dwelling reflects the essence of Yi culture. Residential houses are one of the important contents of human material and cultural creation. In the long historical development, Yi has created a large number of distinctive residential houses according to their special geographical environment. From its history, most of Yi people in the territory have lived in middle and high mountain areas for generations, and few settlements and villages have been built close to the mountain tops and river valleys. Most of them are built on relative gentle hillsides, or basins between the two mountains. There is no unified plan for the layout and arrangement of residential buildings in various settlements and villages. Most of them are arranged according to the geographical location of settlements or villages, without any street.

As a witness to the ancient history and civilization of $\mathrm{Yi}$ and the spiritual home, the traditional $\mathrm{Yi}$ residential architecture is a valuable asset of the traditional Chinese culture. The renovation of traditional Yi dwellings and the construction of small towns blindly copy the construction model of large and mediumsized cities. The destruction of the living environment is caused by economic development and natural disasters. The destruction of the traditional architectural style of dwellings has changed the living environment of Yi, and the dwellings have gradually lost their longstanding architectural features and advantages.

Akhatoyama, renowned Yi scholar, pointed out that in some Yi settlements, some ancient nonrenewable Yi buildings have been demolished driven by blind interests. The construction of so-called highrise buildings with modern flavor, or the random setting up of some development zones do not conform to the local economic development, resulting in the destruction of the regional features of Yi. There are various deviations and mistakes in dealing with economic construction and Yi culture protection. If these problems are not corrected in time, they will cause irreparable losses to Yi culture, even with disastrous consequences. Therefore, it is important to analyze the architectural features and the overall construction mode in Yi accumulation area (Jinling and Yi 2012, Dongfeng 1986, Kejiushe 2008, Nordin et al. 2017).

\section{ARCHITECTURAL FEATURES OF YI SETTLEMENTS IN PANZHIHUA}

Yi in Panzhihua belongs to the Gaoshan nationality. Influenced by the natural environment, religious beliefs and family system, most of them present the pattern of large scattering and small settlement, with the life style of semi grazing and semi farming. Therefore, the natural environment and geographical characteristics have a great influence on the village selection and residence of Yi. Generally, the architectural features of Yi settlements are as follows (Yan and Jun 2013, Roslan et al. 2017, Amin et al. 2018).

\section{Residence near mountains}

Panzhihua is located in the Panxi rift valley, with the landform dominated by low and medium mountains. Restricted by it, most of Yi in Panzhihua live in high and cold mountains, mid-level mountains or valleys. Therefore, the mountainous terrain has a great influence on the location of Yi villages. For defense, Yi people tend to build the villages on the mountainside where the hillside is relatively slow or the terrain is dangerous. When geographical conditions permit, villages are often chosen to face water with their backs to mountains, so there are water sources and cultivated land around the villages used for producing and living. Fig. 1 shows the topographical features of Yangcaozi Gesalayang village in Yanbian County.

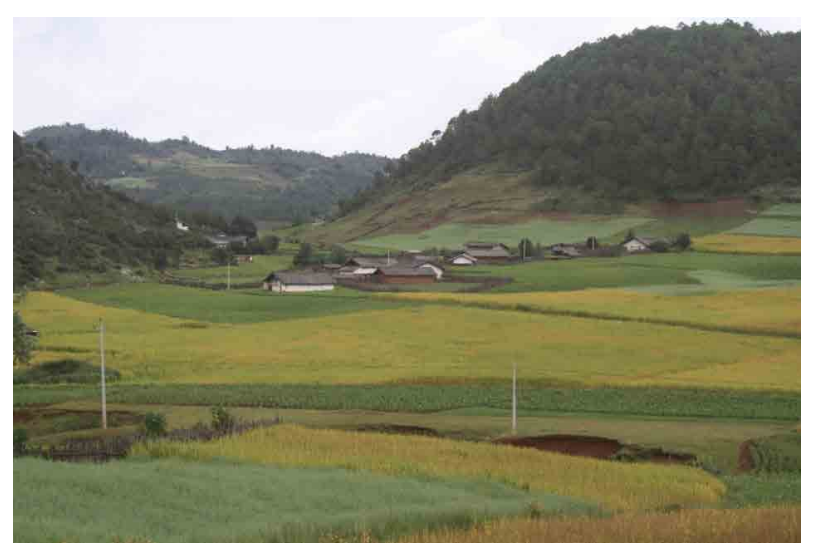

Fig. 1. Yangcaozi Village, Gesalayang, Yanbian County 


\section{Waterproof and shelter from wind}

As the carrier of human beings, environment also restricts their development. Generations of Yi people have gradually accumulated a large number of ways to resist natural disasters in their symbiosis with nature. For example, villages are built with three sides around the mountains or on the ridges to prevent the erosion of houses and villages from floods and mudslides during the rainy season. Mountain winds have adverse impacts on villages and houses in winter and summer, and the blocking of wind by mountains from three sides can prevent villages from being affected and lost (Cheung et al. 2017).

\section{Wind hiding and spirit gathering}

The religious beliefs of Yi affect the site selection, construction and indoor goods placement of villages and houses. Wind hiding and spirit gathering makes the villages located as "concave", which means that they are sheltered by Green Arowana and White Tiger (Baoshi 2004, Gang 1998, Ali et al. 2017). Meanwhile, the vegetation and trees in these places are lush, and the selection and construction of villages here can hide wind and gather spirit.

The simple natural ecology of Yi people has made them attach great importance to the mutual respect between human beings and nature (Usman et al. 2017). It has formed a harmonious coexistence with mountains, that is, a village model of living close to mountains and an environmental model of individual architecture. It fully reflects the mountain complex formed by Nuosu people of Yi due to their perennial high mountain life. Coexisting harmoniously with trees is due to the wood for house structure and roofing tiles. People focus on the protection of tree resources with the habit of planting a tree while cutting down one. Symbiosis with trees is also the hope that the trees around one's house can make his/her family safe and prosperous. On the basis of its natural environment, it is closely related to their life style, such as the cultivation of high mountain crops, the integration of villages into mountains, and the adaption to the living land in high mountains, which fully embodies the simple concept of Yi people when choosing their residence.

\section{ARCHITECTURAL FEATURES OF HOUSES}

Due to the influence of Yi culture and natural environment, different branches of Yi in each region have different architectural styles of residential buildings. The common buildings include bamboo houses, thatched cottages, tile-board houses, log houses and slate houses. Typical Yi residential styles include pitchfork room, wooden rolls-royce room, soil palm room and three rooms and one wall. Tile house is the main type in Yi dwellings in Panzhihua.

\section{Basic characteristics of tile houses}

Tile house, also known as "raw civil structure" dwelling, is another great improvement in the housing as well as the structure of Yi ancestors after pitchfork houses and thatched houses. However, the Yi settlements in Panzhihua are mostly located in mountains with medium and high altitudes. Pitchfork houses and thatched houses are poorly sealed, so it is difficult to shelter the cold mountain wind on the plateau (Khan et al. 2017). Meanwhile, with the social development, the relatively weak enclosure wall can no longer meet people's needs in terms of protection. The economic and social life of Yi people of "Nuosu", who are half ploughed and half grazed, makes them frequently move and change their residence (Chun 2005, Aziz and Hanafiah 2017).

Therefore, the form of "tile house" emerges as required. The wall used as the enclosure structure is made of local raw soil, and forms after compacted shuttering and masonry adobe. It is significantly improved in structural safety, sealing and wind and rain shielding compared with the structure of thatched cottage. The combination of wood-frame bearing and adobe wall enclosure of "wood-bone clay wall" makes the tile house resist natural disasters to a certain extent (See Fig. 2). There are many kinds of combinations of roof truss members such as beams of plank houses, among which bucket piercing and lifting truss are common. These modern classical residential structures reflect the mature wood structure technology in building (Da 2015).

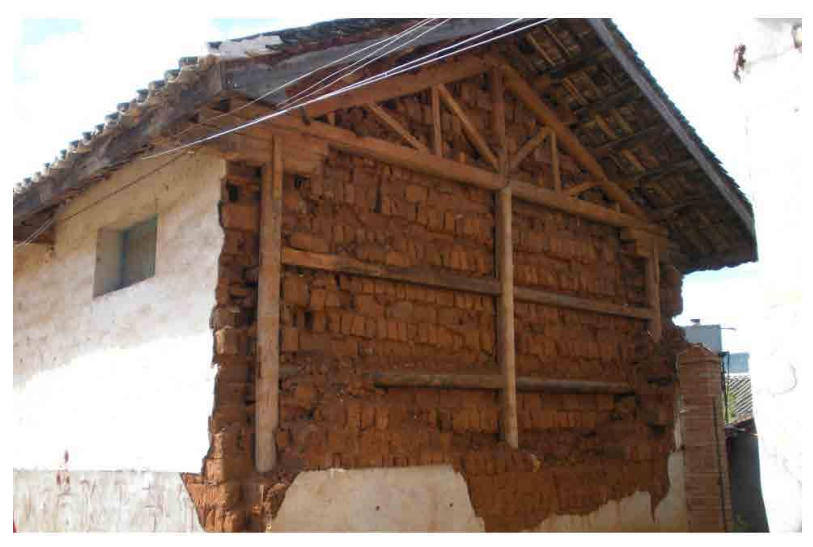

Fig. 2. Yi dwellings with raw civil structure in Miyi County 
The floor area of raw civil structure dwellings has increased, generally $8 * 5 \mathrm{~m}$ square, and the basic division form of the floor layout has been established. The indoor space is divided into left, middle and right rooms. There is a main room or main hall in the middle, without direct partition between the left and right sides of the main room, or the wood partition is used for division. The main partition is the roof truss and the functions of each room (Zhao et al. 2016, Wang et al. 2014). The door is on one side of the room, and the guozhuang is on the other side of the room. The functional division is clear - the main room is for living, visitors, gathering, sacrifice, etc.

\section{Main characteristics of the soil palm room}

The flat-topped adobe house in common dwellings are usually called soil palm room in Yi region. The dwellings are mainly soil palm rooms and buildings. The roof of the residence is a flat-topped bent structure, paved with dense rib beams and columns. Its obvious characteristics are reasonable space layout and durable houses, which is beneficial for fire and theft prevention. Besides, it is warm in winter and cool in summer. Soil palm room is built according to the terrain, making full use of gentle roof. It is the best place for drying grain and family gatherings.

Soil palm rooms are basically built on the hillside, depending on mountains. The shape of internal base can be completely seen from the shape of the building section, which is close to the mountain terrain. It solves the steep slope land for house sites, and avoids a large amount of digging and filling of foundation, which reduces the engineering quantity and time.

Following the custom of ancient $\mathrm{Yi}$, the fireplace is set in the middle of the main building, which is regarded as a symbol of family and is closely linked to the fate of family. Usually the elders live in the main rooms, and the children in the appentice (wing room), which is also used as kitchen or for placing production and living appliances (See Fig. 3 and Fig. 4).

The area and construction of soil palm room depends on the economic conditions of the families and the number of population. Large room has courtyard, and the small room is monolithic, without courtyard. The villages of soil palm rooms are built by mountains, adjacent to the comb. Stacked one upon another and compacted in structure, it looks like a spectacular castle strewn at random from a distance.

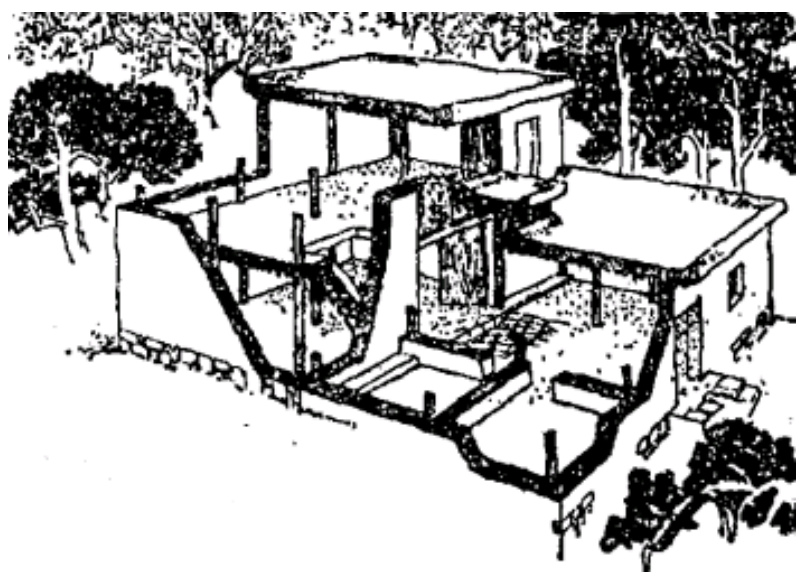

Fig. 3. Spatial layout and plan of soil palm room of Yi

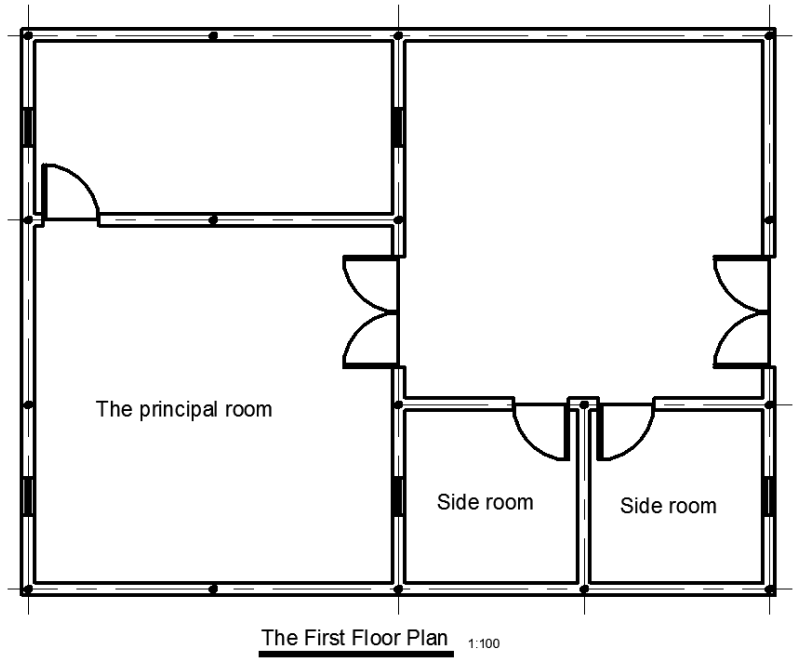

Fig. 4. The floor plan of Yi's TuZhang house

\section{OVERALL CONSTRUCTION MODEL OF HUMAN SETTLEMENT ENVIRONMENT OF YI AGGLOMERATION IN MODERNIZATION}

In the new situation, the social outlook is changing, greatly improving the production and living standards of people. More demands have been proposed on the function and comfort of the living environment. Under the premise of following the respecting the traditional life and production methods of Yi in the area, and building a suitable living environment for Yi to live in harmony with nature and the surrounding ethnic groups, the following principles should be followed. 


\section{Principle of adaptation to nature}

During the planning and construction of Yi dwellings in the new countryside, we should understand the original local topography and geomorphologic features and distribution patters before planning. The original topography and landforms are used to avoid large-scale excavation and filling activities, taking the original local natural, ecological resources and energy resources as the basic materials for the subsequent construction of the artificial natural environment.

Special three-dimensional climate, land and biology are fully used in each concentrated area to construct a modern agricultural system and develop characteristic agriculture such as flue-cured tobacco, walnuts and new mountain breeding. The energy structure is improved by making full use of special natural renewable energy resources such as solar energy and biogas in Panzhihua, which is conductive to the intensive use of resources and the air quality of villages.

The layout of villages and houses should make full use of natural environment and excavate the cultural connotation of local architecture to embody the local characteristics and advantages. To refine the characteristics of the local single residential building, such as the building structure, the local unique raw soil building and the shape and color of dwellings, we should full inherit and use the culture and connotation of Yi dwellings such as layout, architectural features and folk symbols in the subsequent design and construction process. The main features of its design are as follows:

\section{Energy conservation and environmental protection}

With the worsening ecological environment today, energy conservation and rational use of renewable energy have become the consensus of the world. The design is also dedicated to it. Rubble concrete is used as the foundation, with wood frame as the support structure, raw soil for walls, and carved wood boards with rich Yi customs for doors and windows.

\section{Architectural design fully considering the local climate environment}

Panzhihua is a subtropical region with strong solar radiation. The annual average temperature is around $20{ }^{\circ} \mathrm{C}$. The solar radiation in winter and summer is strong, with strong wind in spring and relatively dry climate. The ancient houses of Yi in Panzhihua use a large number of raw soil buildings, which are warm in winter and cool in summer. Their thermal stability is good, with heat accumulation in the walls during the day and heat release at night. The indoor temperature can be adjusted. In addition, the raw soil wall has moisture absorption and release, which is beneficial to adjusting indoor humidity. In most cases, the design considers the influence of shading, wind guidance and heat insulation on the living environment.

\section{Recycling of building materials}

To reduce the use of non-renewable resources and improve the utilization rate of resources, the current houses are located on the original land in the design. Only the foundation is slightly treated to reduce the occupation of land. In addition, the purlin on the original house can be used for beams of newly-built floors.

\section{Preserving the traditional cultural life, and creating suitable living environment}

The local residents are mainly Yi compatriots, so many places in design can reflect their folk customs. For example, there is a courtyard dam at the back of the house, used for family recreation, children's play and preventing various agricultural machinery and appliances such as plowing machines and tractors. This requires that the size of the door opening to the backyard must be large. Therefore, the plan designs the door opening in the backyard of $3.15 \mathrm{~m}$, which is relatively large. Structurally, the lintel on the door opening will be reinforced. The house is designed as a two-story building with a patchwork for facade treatment. The second story is used for living and the first story for stacking. The design meets the physiological and psychological needs of Yi people, which comprehensively deal with relationships between people and environment, and between people and others. It has solved the harmony of various requirements such as usage function, economic benefits, comfort and beauty, and environment atmosphere.

\section{Concept of overall design.}

Although the house building is not complicated, the design is not a simple superposition, but a combination of local folk customs to integrate the buildings into the historical and regional humanities. In the past, Yi people raised chickens and ducks in the courtyard dam, and people and livestock lived together. Only one movable staircase was set up in the house, with poor living environment and space. Different from the previous residential design, the stairs are separated and repaired in the courtyard dam. Pedestrians can reach the living room and bedroom on the second floor directly from the courtyard dam, which is convenient and safe. Meanwhile, the toilet is located beside the courtyard dam alone, thus greatly improving the sanitary condition of residents. 
At this stage, the small towns in various places have developed to be the core of driving the social and economic development in the rural areas of the region. The rapid growth of various small enterprises in rural areas and towns has improved the local industrial structure in rural and remote areas. Rural residents and ethnic minority residents in the region come to villages and towns to do business or work one after another. The collection of information, technology and other resources and labor force has promoted the economy and culture of villages and towns. As a result, the investment in infrastructure in villages and towns is also continuously increasing to further improve the production and living standards of residents.

Under the sustainable development strategy, a harmonious and integrated society should be built between urban and rural areas, which is the functional interdependence between cities and rural areas, and the overall layout in space. Therefore, it is necessary to focus on issues such as the protection of agricultural land resources, the construction of landscaped land, the protection of environment and water resources, the construction of regional infrastructure (including transportation, communications and municipal administration), and the construction of social and cultural facilities (including cultural facilities in urban and rural areas) and the development of regional architecture. Besides, comprehensive assessment should be made on regional construction projects from economy, society and environment (Gao et al. 2017, Si and Qiao 2017, Grzeczka and Szymak 2016).

\section{Principle of diversity}

In the construction of human settlement environment, the potential of Yi dwellings and villages should be fully tapped to recognize their own characteristics and seek various ways of development on the basis of inheritance.

\section{Tourism development}

Under the opportunity of vigorously developing tourism, it is feasible to develop ancient village tourism, historical and cultural folk tourism and other tourism industries. Zhouzhuang in Jiangsu Province, Xidi and Hongcun in An County of Wan'nan are successful examples of ancient villages. This mode of operation not only effectively protects the ancient villages and the living environment, but also enables the local villagers to lead a rich life, which can be described as one-stroke count (Ezer et al. 2016, Khan et al. 2017, Singh and Kewat 2018).

\section{Three-dimensional ecological agriculture}

Panzhihua's rich underground resources are amazing, while the "three-dimensional" surface resources are even more amazing. The climate here takes the south subtropics as baseband, and "latitude" changes as the height of the mountain changes, with the climates of tropics, subtropics, temperate zone and the north temperate zone. The diversity of climate has undoubtedly contributed to the diversification of biology, making Panzhihua have the basic conditions to become a characteristic agricultural base.There is no need for "plastic greenhouses" for planting out-of-season vegetables and fruits here. As experts said, there are "temperatures in the south and light in the north".

\section{Rural tourism}

Rural tourism with Yi customs is also another carrier of Yi folk customs, folk houses, music and other cultural dissemination and promotion. The development and construction of rural tourism drives the economic income of residents in Yi concentrated area, thus enabling them in improving the living environment of the residents.

\section{CONCLUSION}

Starting from the current era and the scientific theory of human settlement environment, the work expounded and summarized the characteristics of Yi dwellings and human settlement environment in Panzhihua. The current scientific theoretical methods and technological achievements were combined to effectively inherit and utilize the wisdom in Yi living environment, organically transforming it into a scientific regional construction mode and principle. It provides rich inspiration and references for the regional restoration and the construction of living environment, which makes the traditional dwellings in ethnic minority areas inherited and reborn.

\section{ACKNOWLEDGMENT}

The authors were sponsored by the National Natural Science Funds (NO. 41372340 and NO. 41671432), Key Laboratory of Geoscience Spatial Information Technology of Ministry of Land and Resources, Chengdu University of Technology (NO. KLGSIT2016-10), Sichuan science and technology innovation miao sub-project, China (NO. 2017025), Sichuan Statistical Science Research Project(NO.2018sc28). 


\section{REFERENCES}

Ali S.S., Ijaz N., Aman N. and Noor M. (2017). Feasibility Study of Low Density Waste Plastic in Non-Load Bearing Asphalt Pavement in District Faisalabad. Earth Sciences Pakistan. 1(2), 14-15.

Amin F., Talpur F.N., Balouch A., Afridi H.I. and Khaskheli A.A. (2018). Efficient entrapping of toxic $\mathrm{Pb}$ (II) ions from aqueous system on a fixed-bed column of fungal bio sorbent. Geology, Ecology, and Landscapes. 2(1), 39-44.

Aziz N.I.H.A. and Hanafiah M.M. (2017). The Potential of Palm Oil Mill Effluent (POME) As A Renewable Energy Source. Acta Scientifica Malaysia. 1(2), 09-11.

Baoshi H. (2004). The civil residence architecture of Liang Shan Yi and rerserch on its architecture culturl phenomena. Chongqing University.

Cheung Y., Lam O., Lun S., Pang C., Wu K.W. and Leung W.K. (2017). Electrical Stimulation for Eggs and Semen on Tavhypleus Tridentatus Collected from Local Restaurants in Hong Kong. Malaysian Journal of Sustainable Agriculture. 1(2), 01.

Chun C. (2005). Living environment of the humanized design. Chongqing University.

Da W. (2015). Three Tongues and Two Identities:A Case Study of Ersu Ethnic Identities in Sichuan,China. Cultural Diversity in China, 1 (1), 44-67.

Dongfeng G. (1986). Yi's architectural culture and grasp---- the theory of building the prototype and constructed deep concept, Yunnan People's Publishing House.

Ezer T., Haigh I.D., and Woodworth P.L. (2016). Nonlinear Sea-Level trends and Long-Term variability on western european coasts. Journal of Coastal Research. 32 (4), 744-755.

Gang M. (1998). High-altitude mountainous southwest design technology preliminary thought and a review of the Panzhihua city construction. Architectural Journal, 6, 12-16.

Gao W., Wang Y., Wang W., and Shi L. (2017). The first multiplication atom-bond connectivity index of molecular structures in drugs. Saudi Pharmaceutical Journal. 25 (4), 548-555.

Grzeczka G., and Szymak P. (2016). The hardware implementation of demonstrator air independent electric supply system based on pem fuel cell. Polish Maritime Research. 23 (4), 84-92.

Hamad J.R.J., Hanafiah M.M. and Yaakob W.Z.W. (2017). Water Resources Management in Libya: Challenges and Prospects. Malaysian Journal of Sustainable Agriculture. 1(2), 02-05.

Haruna S.N. and Hanafiah M.M. (2017). Consumptive Use of Water by Selected Cash Crops in Malaysia.
Malaysian Journal of Sustainable Agriculture. 1(2), 06-08.

Jinling F., and Yi, L. (2012). Architectural Context and Its Expression in the Inheritance and Development of Modern City, Chongqing University.

Kejiushe A. (2008). (Sorrow is hushed into Yi's culture. Liangshan daily, (2).

Khan A.M., Yusoff I., Abu Bakar N.K., Abu Bakar A.F., Alias Y., and Mispan M.S. (2017). Accumulation, uptake and bioavailability of rare earth elements (rees) in soil grown plants from ex-mining area in perak, malaysia. Applied Ecology and Environmental Research. 15 (3), 117-133.

Khan I.U., Sajid S., Javed A., Sajid S., Shah S.U., Khan S.N. and Ullah K. (2017). Comparative Diagnosis Of Typhoid Fever By Polymerase Chain Reaction And Widal Test In Southern Districts (Bannu, Lakki Marwat And D.I.Khan) Of Khyber Pakhtunkhwa, Pakistan. Acta Scientifica Malaysia. 1(2), 12-15.

Nordin N.F.H., Idris S.N.N.M., Nawi M.N.M., John A. and Chowdhury A.J.K. (2017). Pcb Biodegration Using Bacteria Isolated from Landfill Leachate. Science Heritage Journal. 1(2), 8-11.

Roslan M.A.M., Mohamad M.A.N. and Omar S.M. (2017). High-Quality Dna From Peat Soil for Metagenomic Studies: A Minireview On Dna Extraction Methods. Science Heritage Journal. 1(2), 1-7.

Si L. and Qiao H. (2017). Performance of Financial Expenditure in China's basic science and math education: Panel Data Analysis Based on CCR Model and BBC Model. Eurasia Journal of Mathematics Science and Technology Education. 13 (8), 5217-5224.

Singh A., Kewat M.L., and Sondhia S. (2018). Studies on the effect of day time application of herbicide mesosulfuronmethyl on soil microbial communities of wheat rhizosphere. Journal of Environmental Biology. 39 (1), 59-65.

Usman M., Yasin H., Nasir A. and Mehmood W. (2017). A Case Study of Groundwater Contamination Due to Open Dumping of Municipal Solid Waste in Faisalabad, Pakistan. Earth Sciences Pakistan. 1(2), 12-13.

Wang Y.M., Dong D.Z., and Yang H. (2014). Quantitative characterization of reservoir space in the Lower Silurian Longmaxi Shale,southern Sichuan, China. Science China Earth Sciences, 57 (2), 313-322.

Yan W., and Jun S. (2013). Association Study on Regionality and Ethnicity of Building in the Minority Settlements of Northwest Yunnan. Architectural Journal. 5, 95-99.

Zhao M., Harshaw H., and Li Y. (2016). Interpretive satisfaction of Chinese visitors at the Southern Sichuan Bamboo Sea: Importance-Performance Analysis approach. International Conference on Service Systems and Service Management. IEEE, 1-6. 